\title{
O LIRISMO EM GYÖRGY LUKÁCS
}

\author{
Arlenice Almeida da Silva* \\ arlenice@uol.com.br
}

RESUMO O artigo visa a examinar o tratamento dado ao lírico na obra estética do jovem Lukács. Em A alma e as formas o autor examina a poesia de Stefan George, encontrando nela elementos formais que apontam para o surgimento de um novo lirismo. Tal "forma significativa" possibilita ao autor introduzir uma abordagem do conceito de modernidade, em viés crítico e fenomenológico. Empreendimento que será completado em A teoria do romance, quando a tendência lírica se apresentará exacerbada, contaminando e alterando as configurações dos demais gêneros.

Palavras-chave Poesia; Estética; Gênero; Estrutura Significativa.

ABSTRACT The paper aims to examine the treatment of lyrical in the aesthetics work of the young Lukács. In The Soul and the Forms the author examines the poetry of Stefan George, finding on it formal elements that point out to the emergence of a new lyricism. This "significant form" allows the author to introduce an approach of the concept of modernity, in critical and phenomenological bias. Work that will be completed in The theory of Love, when the lyric trend will be exacerbated, contaminating and altering the settings of the other genera.

Keywords Poetry; Aesthetics; Gender; Significant Structure.

* Doutora em filosofia pela USP e professora de Estética e História da Arte do Departamento de Filosofia da UNESP, campus de Marília. Artigo recebido em fev. 2008 e aprovado em 17 dez. 2008.

KRITERION, Belo Horizonte, no 119, Jun./2009, p. 93-113. 
Um dos temas que cativam e, ao mesmo tempo, dificultam o acesso à obra estética do jovem Lukács é o do emudecimento (Verstummung), conceito que designa a perda da palavra. Mas, diante de um autor tão prolixo e de uma obra tão vasta, que silêncio é este? Trata-se de um silêncio da alma ou da forma? De um sintoma psicológico ou de um signo da modernidade? Com efeito, poderse-ia pensar tratar-se do seu próprio mutismo que consistia ora em uma reserva e embaraço diante de um outro, ora, em seus termos, em "forte repugnância em falar", ao não se sentir escutado; ao perceber-se sujeito de uma fala vã, e na constatação amarga de que em quase toda sua vida, especialmente na juventude, "não havia conseguido estreitar laços com as pessoas que lhe eram mais importantes", como Endre Ady ou Bela Bartók (LUKÁCS, 1986, p. 5152). Nos textos, contudo, paradoxalmente, o embaraço pessoal dissipa-se e confunde-se com o tema de um emudecimento geral que remete diretamente para a impossibilidade mais aguda da própria forma, vista como um sintoma da modernidade. Mas, estamos diante da constatação da impossibilidade da própria poesia, que outrora podia dizer o essencial e que agora suspira pela palavra poética reparadora, que vá restituir a consistência originária perdida? Ou, inversamente, estamos na direção de uma "estética do silêncio", silênciopausa que se abre como vazio e pura forma, como ato originário criativo, permitindo à linguagem dizer o que ainda não foi dito?

Certamente no jovem Lukács o silêncio não decorre de uma incomunicabilidade positivada, signo de uma modernidade transgressiva e que busca dizer o inefável. Tampouco o mutismo pode ser explicado ao acaso, psicologicamente, por meio de motivações pessoais: o plano subjetivo é insuficiente, pois unívoco e parcial — apesar de ele ser legítimo e sempre um lado essencial do problema, afinal é sempre da vida vivida individualmente que se trata. Não se trata, pois, de uma situação contingente, mas nem por isso estamos diante de uma necessidade imposta por alguma lei universal; de um silêncio que apontaria para uma "dor inexprimível" que, por exemplo, nos termos de Schopenhauer, teria raízes na natureza do homem. Assim, encontramo-nos diante de uma condição existencial e temporal que aponta para um quadro geral de incomunicabilidade e que conduz a uma obscuridade na e pela linguagem e a uma impossibilidade do sentido. Precisamente, estamos diante de uma fratura ocorrida no campo da arte, pois algo foi perdido na relação entre arte e vida, já que "a arte se tornou estrangeira em relação às suas origens" (Ursprung- Fremden aufgewachsen sind) (LUKÁCS, 1974, p. 188). Para entender o emudecimento como um sintoma geral da modernidade e não pessoal de algo que se perdeu, é fundamental para o jovem Lukács articular as relações entre a alma e as formas. Ora, o que a forma tem a ver com este 
silêncio? Como a obra de arte, particularmente a poesia lírica, pode ser uma maneira de violar o mutismo?

Em suas obras iniciais o quadro "pré-existencial" desenhado é bastante sombrio, mas também crítico: se não podemos na contemporaneidade conhecer definitivamente o mundo, o "destino" na linguagem de Lukács, eivado de acasos e em constante transformação, podemos menos ainda conhecer os homens, seus desejos e ações. O mutismo corresponde à dissonância, conceito que caracteriza os equívocos interpretativos, jogos de ilusão e desilusão que definem a modernidade: "Tudo que podemos saber sobre um outro é que ele é apenas espera e possibilidade"; na infinidade das múltiplas possibilidades, "tudo é possível, mas nada é certo e tudo se confunde" (idem, p. 180). Para Lukács, tal constatação separa o "mundo da compreensão" do "mundo da vida", abrindo-se então uma fissura na qual a própria existência é apresentada por meio da metáfora do abismo: imagem figurada como uma subida ao topo de uma montanha que acaba em precipício. Os poucos que atingem o topo podem vislumbrar por um instante as múltiplas possibilidades e caminhos que se abrem, mas a reação diante do ilimitado e do abismo que separa o pico da base é a sensação de vertigem e, consequentemente, a constatação do estado de solidão e o emudecimento. E não a reação sugerida por Kant, no sublimematemático diante do absolutamente grande, isto é, a de uma "comovedora complacência que tem seu fundamento em idéias morais (...) e que desperta o sentimento de uma faculdade supra-sensível em nós" (KANT, 1993, p. 96).

Ao situar a cisão entre entendimento e vida como o problema contemporâneo da arte, Lukács articula uma Estética a partir de pares de opostos: forma viva e forma abstrata; forma autêntica e inautêntica; Vida e vida; e lirismo antigo e lirismo novo. De modo que há nos conceitos desta fase da produção lukácsiana uma reflexão estética, segundo Lucien Goldmann, pautada por uma "síntese entre um estruturalismo mais ou menos fenomenológico de matriz husserliana e um kantismo trágico". Da primeira corrente fenomenológica, tendência marcante na escola de Freiburg-im-Breisgau, que influenciara Lukács, sobressai o conceito de "essência como estrutura significativa" ou de "forma significativa". Do kantismo conflui o método, na medida em que a reflexão conceitual do autor parte do procedimento crítico, ou seja, de uma consciência que pensa os limites do conhecimento, e, radicalizando, afirma a solidão e a impossibilidade de dizer uma verdade absoluta sobre o mundo. Da confluência entre estas duas tendências desponta uma Estética que parte da consideração de uma obra particular, tomada como necessária, ou seja, à qual é atribuído um valor universal: a obra é um julgamento de valor, uma escolha ética, isto é, a busca de uma ordem e de uma harmonia em uma forma, a partir 
de uma subjetividade. O trágico, portanto, resultaria de uma verdade instável fundada a partir destas formas particulares, problemáticas e dissonantes, e, no entanto, formas significativas, pois apontavam dialeticamente para essa ruptura insuperável entre o homem e o mundo. ${ }^{1}$

É o que se pode constatar, sobretudo, em A alma e as formas (1910), obra central das primeiras incursões de Lukács no campo da Estética. Ali a questão da forma já ganhava alguns poucos contornos históricos, indicando a direção da historicização que ocorrerá com mais força a partir de A teoria do romance (1916). No ensaio "A nova solidão e seu lirismo: Stefan George", o jovem Lukács enfrenta o tema da poesia contemporânea, isto é, do início do século XX, considerada pela crítica literária da época estetizante, fria, hermética e distante. Investigando a pertinência de tais predicados, Lukács vai além, perscrutando e explicitando o significado desta frieza e impassibilidade, pois elas apontavam não só para uma crise na poesia, mas para o surgimento de um novo lirismo. ${ }^{2} \mathrm{O}$ diagnóstico é ainda indefinido, mas incontornável: o fato de que uma poesia seja considerada obscura e não comunique mais alguma coisa a um público não depende apenas da crise da poesia, mas do ordenamento de uma situação histórico-cultural; hoje, diz Lukács, "as formas não se desenvolvem mais a partir da vida, ou elas são abstratas ou inexistentes" (LUKÁCS, 1974, p. 189).

No que consiste a crise, e o hermetismo de George, pergunta Lukács? Seria um novo classicismo, que se apresentaria após o esgotamento do fluxo romântico? Do ponto de vista da história da arte, ainda influenciada por uma reflexão romântica, como a de Friedrich Schlegel, seria uma interpretação plausível, na medida em que nesta os conceitos de clássico e romântico flutuam, obedecendo a uma dialética antitética, na qual o excesso de subjetividade do período anterior é suplantado e encontra sua solução na objetividade da fase posterior. Ora, Lukács confronta Schlegel ao afirmar que os conceitos de "objetividade e subjetividade são categorias da evolução e da história, mas não da estética" (p. 134); são categorias de uma história da recepção do leitor que,

1 Cf. GOLDMANN, Lucien. L'esthétique du jeune Lukács. In: Marxisme et sciences humaines. Paris: Gallimard, 1970. Para Goldmann, em A alma e as formas Lukács reata com a grande tradição da filosofia clássica ao definir significação pela relação entre a alma e o absoluto. Por outro lado, ao situar a autenticidade na consciência dos limites e da morte ele sustenta até o fim uma visão trágica que desemboca na recusa do mundo e de todas as formas inautênticas. Cf. Introduction aux premiers écrits de Lúkacs. In: LUKÁCS, G. La Théorie du Roman. Paris: Denoël, 1968. p. 166-168.

2 A novidade e ousadia dos textos de Lukács, o seu caráter independente em relação ao cenário cultural húngaro e sua disposição de dialogar com a literatura estrangeira, especialmente a alemã, podem ser percebidos na cautelosa recepção que o livro obteve entre os críticos literários húngaros. Seu texto foi acusado de "estrangeirismo", "de aristocratismo formal", "hermetismo", ou seja também o jovem ensaísta Lukács era acusado de ser "estetizante" (ÁRPÁD, 1988, p. 7-23). 
diante de uma obra poética, busca uma relação de causalidade, de identidade e semelhança; versos que eram lidos como objetivos, frios e clássicos podem ser vistos anos depois como subjetivos, quentes e líricos. Ou seja, nada que diga respeito ao "valor da obra", mas a sua posição social num contexto histórico, pois especificamente elas sinalizam as mudanças sentimentais que ocorrem no tempo. ${ }^{3}$

Mas, do ponto de vista da estética, trata-se de enfrentar o lado mais complexo do problema, afirma Lukács, que é o de compreender o valor de uma obra, entendê-la como "estrutura significativa," superando, assim, a vacuidade e a instabilidade dos conceitos de objetividade e subjetividade. A Estética deve enfrentar os problemas formais internos de uma obra de arte, e no caso especialmente da lírica de Stefan George, levar em conta, como propusera Goethe, que "o lírico moderno é um poeta de ocasião, que se angustia diante do gênero literário sem saber o que fazer", mesmo sabendo que seus versos provêm da "influência recíproca da individualidade do poeta e das circunstâncias de seu tempo" (p. 135).

De modo que, se George é um esteta, considerado frio e hermético, ele o é na condição de moderno: aquele que cria sua própria forma a partir de si mesmo; pois já não se satisfaz com as formas do lirismo habitual. Contudo, o esteta não resulta apenas de um voltar-se para uma interioridade rica e livre, mas igualmente de uma reação diante de uma "época não artística", caracterizada por uma "incapacidade de leitura do leitor contemporâneo"; trata-se de uma forma do poema que exige um "leitor estrangeiro, ideal, que não existe em parte alguma". Nos seus termos, "esteta é aquele que nasceu em uma época na qual o sentimento racional da forma desapareceu (rationelle Formgefühl ausgestorben ist), que não se resigna diante das formas convencionais, transmitidas historicamente, como resíduos mortos (...) e que, ao contrário, na medida das suas possibilidades, constrói em si mesmo suas determinações específicas e cria a partir de si mesmo as circunstâncias que determinam seu talento" (p. 136). Ele ainda pretende dizer alguma coisa, em uma época na qual o lirismo habitual não tem mais nenhum papel na vida corrente.

3 Para F. Schlegel não é possível reproduzir no presente a perfeição dos gregos, ou seja, a Antiguidade foi um acontecimento único, perfeito e encerrado, mas "a história da formação da poesia moderna representa o constante conflito entre a predisposição subjetiva e a tendência objetiva da capacidade estética e o paulatino predomínio da última. Com cada mudança na relação do objetivo com o subjetivo começa um novo grau de formação (...) a autêntica beleza tem que primeiro deitar raízes em muitos pontos soltos, antes de poder estender-se em toda a superfície, antes que a poesia moderna possa alcançar a próxima fase de sua evolução: o domínio absoluto do objetivo" (SCHLEGEL, 1996, p. 144-148). 
Assim, paradoxalmente, tais formas são abstratas e significativas — pois são artificiais e negativas: formas de resistência ao tempo. A partir delas o autor pode elaborar uma reflexão original sobre os gêneros, e aqui, em particular, sobre a poesia lírica, localizar uma novidade, "o lirismo pudico (keusche Lyrik)", e pensar a partir desse referencial artístico o "problema espiritual (seelisch) do homem contemporâneo". Curiosamente, não é a forma nomeada de "intelectualmente moderna" que permite ao autor investigar as marcas do contemporâneo, mas uma outra forma, paralela, também experimental, mais clássica, nomeada de "a nova poesia da palavra" (der neuen Wortdichtung). Tal contexto assinala para o autor o declínio da tradição do canto popular e a ascensão do lirismo musical de formato inglês - o qual de certa forma o maduro Goethe já antecipara o quadro e Stefan George, o discípulo alemão de Mallarmé, será o principal nome deste novo lirismo. Vejamos um exemplo deste movimento no poema de George, intitulado "Nietzsche":

Escuras nuvens avançam sobre a montanha

Gélidas tempestades fustigam — ainda meio outono

Meio primavera... Eis a muralha

Que encarcerou o Trovejador - era o único

Entre os milhares de pó e névoa ao seu redor?

Ali lançou seus últimos relâmpagos rebotos

Sobre planícies e cidades extintas

Transpondo a longa noite para a noite eterna.

Crassa trota abaixo a massa — não a espantem!

Seria ferir a medusa - ceifar erva!

Em instantes impera o silêncio celestial (...)

Tu redentor! De todos o mais infeliz -

Marcado pelo destino atroz

Nunca viste a sede da saudade sorrir?

Criaste deuses para logo despedaçá-los

Nunca uma obra te deu alegria ou alívio?

Aniquilaste em ti próprio o próximo

E ao sentires sua falta na absoluta solidão

Soltaste um grito de dor e desespero

Tarde demais chegou o suplicante para revelar-te:

Não existem caminhos sobre cimos nevados

E pássaros apavorados ouviste - na miséria:

Exilado no círculo onde o amor inexiste.

E quando a implacável e atormentada voz

Soa como canto de louvor em soturnas noites

De luar - assim lamenta-se: devia ter cantado

Essa nova alma e a palavra evitado!

(GEORGE, 2000, p. 99) 
A oposição entre cantar e falar assinala o sinal dos tempos, o elemento trágico da solidão e do isolamento. Ao enfrentar o problema espiritual da contemporaneidade, qual seja, o da proximidade e do afastamento da arte em relação à vida e que se traduz na opacidade da palavra, Stefan George constata, nesse poema, que a "muralha que encarcerou o trovejador" e que exilou o filósofo no "círculo onde o amor inexiste" está prestes a provocar o "silêncio celestial", enquanto "crassa trota abaixo a massa". Não há reconciliação possível entre o poeta que é o "único" e os "milhares de pó e névoa", habitantes de "cidades extintas"; não há também redenção pela palavra, que tão somente é "voz atormentada", pois não alivia nem dá alegria. É uma poesia que chega tarde demais, sem nostalgia, lamentando-se não pelo tempo passado, mas pelo instante do presente que acabou de ser perdido e que se esvai. Seu lirismo marca uma literatura que se constitui, portanto, a partir de uma distância radical. Uma literatura do distanciamento e da solidão, e não da aproximação e da comunhão.

Por que tal forma é para Lukács significativa? De um lado, o fazer do poeta aponta para a noção de intencionalidade, de resistência formal: a linguagem oscila, aproxima-se e afasta-se das coisas, sem abandonar o sensível, visando tornar-se estrangeira, sugerindo uma comunicação interrompida ou perturbada. De outro, a linguagem abre mão de referir-se às coisas absolutamente, mas não abre mão do absoluto, entendido como o essencial, evitando, assim, o risco de a forma apontar apenas para o que é casual, vulgar, para aquilo que é inteiramente singular e, portanto, inessencial. Uma combinação inusitada, uma beleza intrigante: tal forma é original e exige uma teoria correspondente, sustenta Lukács. Pois aqui não se trata nem de uma "metafísica imanente", como em Schopenhauer, para quem o "poeta idealiza a natureza", na medida em que o que é significativo é em si mesmo e não pelas relações que estabelece, de modo que o poeta "constrói a priori aquelas proporções numa intuição pura, não empírica, estabelecendo-as, portanto, não como elas se encontram efetivamente nas figuras assinaladas, mas como são na idéia" (SCHOPENHAUER, 2003, p. 208). E nem da estética hegeliana e da definição da lírica como a expressão de um sujeito que fala a si mesmo, apesar de o jovem Lukács estar bastante próximo do idealismo hegeliano: "O que conduz à poesia épica, diz Hegel, é a necessidade de ouvir a coisa a qual desdobra diante do sujeito a totalidade fechada por si mesma como uma totalidade objetiva em si mesma; na lírica, ao contrário, se satisfaz a necessidade inversa de se expressar a si e de perceber o ânimo na exteriorização de si mesmo" (HEGEL, 2004, v. 4, p. 157). Ou, nos termos mais claros dos cadernos de Kehler: "O objeto da poesia lírica é o interior em seu modo de sentimento, no modo de 
elaborar em si mesmo e produzindo representações que não se mostram em conexões com as ações". ${ }^{4} \mathrm{Ou}$ seja, o lírico é um momento de emancipação do eu, da efusão (Erguss) da subjetividade, na qual figura "o espírito que não deve ser libertado do sentimento, mas no sentimento". Aliás, no sistema geral da Estética de Hegel a poesia é o momento de maior abstração, com quase nenhuma presença de matéria sensível.

Ou seja, um Lukács estritamente hegeliano deveria enfrentar se não muitos, pelo menos os problemas inerentes ao polêmico tema do fim da arte, enunciado por Hegel: "Por esta razão, o estado de coisas da nossa época não é favorável à arte"5 (HEGEL, 1999, p. 35). O primeiro seria o de enfrentar o diagnóstico histórico de que se trata de uma transformação na "natureza de toda a cultura espiritual" e que nenhum artista pode escapar a essa situação, "e formar uma solidão particular restauradora do que se perdeu" (idem). O segundo, de que a solidão do poeta é também, na Estética de Hegel, interiorização, positividade, representação, pois é um momento no curso do espírito no mundo, isto é, uma figura do espírito, que se situa entre um momento anterior no qual predominou a objetividade do épico e em um posterior, no qual se dará a síntese no drama. Ora, o tema do fim da arte está presente em $A$ alma e as formas, mas só será desenvolvido plenamente em $A$ teoria do romance.

Em $A$ alma e as formas, o que possibilita o surgimento de uma nova lírica é o isolamento, o afastamento da "cultura espiritual" de sua época, provocado pela reação diante de "um tempo que não é favorável à poesia"; é a impossibilidade de uma "cultura pública", de "uma alma e uma voz nacionais", no sentido antigo, ou seja, a solidão do "homem arrancado de todos os laços sociais", mas que não cessa de desejar alguma forma de pertencimento. Poderíamos dizer que há, portanto, uma inversão: é do exterior

4 HEGEL. Caderno de Kehler, p. 396-397 (apud WERLE, 2005, p. 193).

5 O tema do fim arte em Hegel foi e continua sendo controvertido. "O caráter peculiar da produção artística já não satisfaz mais nossa alta necessidade. Ultrapassamos o estágio no qual se podia venerar e adorar obras de arte como divinas. A impressão que elas provocam é de natureza reflexiva e o que suscita em nós necessita ainda de uma pedra de toque superior e de uma forma de comprovação diferente" ( $p$. 34). O diagnóstico de Hegel é definitivo, apesar de localizar em Schiller, e, especialmente, em Goethe o ápice de maior produção da poesia lírica, e, de certa forma seu momento de exceção: "Klopstock (...) e se ele também permanece segundo alguns aspectos preso à limitação de sua época e compôs muitas odes meramente críticas, gramaticais e métricas, frias, todavia desde então, afora Schiller, ninguém surgiu novamente com tal figura nobre independente em mentalidade viril séria. Ao contrário, Schiller e Goethe viveram não meramente como tais cantores de seu tempo, mais como poetas mais abrangentes e particularmente as canções de Goethe são o que há de mais excelente, profundo e eficaz que nós alemães dos dias de hoje possuímos, pois elas pertencem inteiramente a ele e ao seu povo e, tal como cresceram no solo familiar, correspondem também completamente ao tom fundamental de nosso espírito" (HEGEL, 1999, v. 4, p. 200). 
que parte o solo propício para a nova lírica e não do "ânimo", da vocação, da interioridade. $\mathrm{O}$ que Goethe já havia de certa forma percebido e operado dialeticamente: "pois as determinações específicas (da poesia moderna) deveriam, se não me equivoco, vir do exterior, e as circunstâncias determinar o talento", sublinha Lukács (LUKÁCS, 1974, p. 136). Se o elemento externo se apresenta determinante, cujo conteúdo é um puro desinteresse em relação à arte, em que medida a poesia de George afirmaria a autonomia da arte, seu momento emancipatório?

O conceito de autonomia ganha nos ensaios de $A$ alma e as formas uma tradução desencantada. O que significa que Lukács leva realmente a sério a ideia hegeliana de que uma subjetividade não pode saltar, por seus próprios meios, por cima do seu tempo. E o tempo é o da dissonância, da nostalgia, da impossibilidade da essência, da ausência de sentimentos comuns, enfim, da busca infeliz. Se, ainda em Hegel, Schiller marcava o momento mais "agudo" da lírica, pois "ele não canta silenciosamente em si mesmo" (HEGEL, 2004, v. 4, p. 190), para o jovem Lukács não há reconciliação possível pois a solidão de George remete a uma ausência que assinala uma nostalgia de formato clássico — "ninguém tem necessidade de suas lieder" — que permite uma configuração sensível da intimidade, um mergulho na interioridade sem precedentes, um devotamento aos seus "cursos interiores", àquilo que na sua experiência é o mais pessoal. Mas a exigência de intimidade resulta em perda, em distanciamento em relação à vida.

De modo que, negativamente, tal mergulho "não anuncia nada de verdadeiramente decisivo sobre seu verdadeiro ser", diz Lukács, enquanto para Hegel o poeta lírico assinalaria um momento de conscientização e de exteriorização do percebido, um momento no qual o poeta "expõe a si mesmo", "a totalidade de um indivíduo segundo o seu movimento poético interior" (HEGEL, 2004, v. 4, p. 175). Em George, tal lirismo que se atém ao que é mais pessoal adota um tom de despistamento, de forte inspiração de seu predecessor Mallarmé, como se procurasse dissimular os elementos confessionais, evitando, assim, qualquer identificação e reconhecimento por parte do leitor. Lukács demonstra que o procedimento, se não resulta como em Mallarmé no aniquilamento da realidade, decorre de um afastamento de toda a realidade empírica, portanto, de um lirismo que negativa e intencionalmente se afasta de qualquer comunhão com o leitor. Lirismo "simbólico", "universal", mas, principalmente, "pudico" (Keusche), "enigmático". Procedimento que coloca o poeta cada vez mais solitário e afastado da vida.

A mudança é percebida principalmente no plano formal e exige uma reformulação na poética dos gêneros. Pois o lirismo antigo era, diz Lukács, uma 
poesia de circunstância, destinada a um leitor geral, simples, pouco informado, mas conhecedor do sentido existente, das oposições que localizavam uma aventura ou um ato heroico. De modo que tais versos eram destinados a ser posteriormente cantados, em uma música própria para vozes coletivas. Ou seja, o poema efetivava-se no canto. No lirismo moderno, ocorre o fim do acompanhamento musical, do canto, não só pelo declínio da experiência comunitária que engendra o canto, mas porque a poesia já é nela mesma música, "ao mesmo tempo texto e entonação, melodia e acompanhamento" (LUKÁCS, 1974, p. 142); evocação das tonalidades da alma, apenas por meio da sonoridade das palavras, ritmo que resulta da alternância entre sons e silêncio. Ou seja, estamos diante das condições formais que possibilitam a autonomia da obra de arte.

Do ponto de vista técnico, o procedimento consiste em uma inversão notável, diz Lukács: "se em Heine, Byron e no jovem Goethe, a experiência vivida era concreta e o poema consistia em torná-la típica, elevando-a ao símbolo", em George, ao contrário, é a experiência vivida nos seus mínimos detalhes e percepções casuais que é elevada ao típico (typisiert das Erlebnis) e a poesia revela apenas as modulações das emoções, tornadas enigmáticas e sem significação imediata, impedindo a simbolização. "Naturalmente, ele (George) fala sempre de si mesmo, contando tudo aquilo que para ele é mais profundo, mais dissimulado, e a cada confissão ele torna-se mais enigmático, fechandose cada vez com mais força em sua solidão" (LUKÁCS, 1974, p. 138). ${ }^{6}$ Trata-se, nomeia Lukács, do "impressionismo do típico", de versos feitos de alusões, imprecisões, detalhes; coloridos e sons que se perdem, transformamse uns nos outros, deslocam-se, mas que mantêm o "poeta permanentemente afastado de nós, leitores" (idem, p. 139). Eles são íntimos demais, impedindo uma significação clara, simples e, portanto, universal. Encontramos apenas uma "atmosfera", diz ele, que permite que o visível surja entre as coisas, "no reflexo cintilante de suas superfícies e na indefinição de seus contornos", de modo que o inexprimível possa permanecer como inexprimível (LUKÁCS,

6 É interessante comparar a definição de lirismo no jovem Lukács com a de Schopenhauer, e perceber a modernidade do primeiro e a dimensão ainda moral do segundo. Para o último, a poesia lírica decorre da exigência do "idealístico" na exposição do caráter: "todas as anomalias do caráter têm de permanecer excluídas da pessoa, a qual tem, em sua ação e fala, de manifestar seu caráter de maneira conseqüente, clara, pura e exata. Isso significa justamente que o caráter tem de ser exposto de modo idealístico; apenas o essencial dele, por inteiro, deve ser mostrado, permanecendo excluído qualquer elemento casual e perturbador" (SCHOPENHAUER, 2003, p. 216). Em outros termos, a poesia lírica resulta da confluência do "sujeito do querer com o sujeito do conhecer"; o que fica especialmente nítido na essência específica da canção: a sensação desse contraste (entre o querer, a vontade própria, e o conhecer puro destituído de vontade) desse jogo de alternativas é propriamente o que se exprime em toda canção e constitui em geral o estado lírico" (idem, p. 212). 
1974, p. 172). Posteriormente Adorno dirá que não há comunhão possível entre o leitor e os versos de George, pois "são poemas que não permitem intimidades" (ADORNO, 1998, p. 206). ${ }^{7}$

Os versos de George falam de olhares que não foram percebidos, palavras não ditas ou não compreendidas, de instantes e transições. Para Lukács, a novidade que o lirismo de George anunciava, e que já estava prenunciada como vimos no maduro Goethe, consistia em demonstrar que no mundo contemporâneo predomina cada vez mais um estranhamento, e que o desejo de pertencimento e de comunhão só podia ser enunciado por um murmúrio e negativamente. Eis a técnica do recuo, da relação recíproca entre aproximação e afastamento, que é na verdade a outra face da tensão entre o que pode ser narrado e aquilo que não encontra palavras para ser dito. Para o jovem Lukács, no mundo contemporâneo, isto é, na modernidade, a proximidade tornou-se tão intensa, de modo que tudo parece passível de ser narrado, o que não significa um acesso mais amplo ao que importa, ao essencial. Ou seja, é diante da mais absoluta proximidade que reside a mais terrível obscuridade; na compreensão de tudo, a mais absoluta incompreensibilidade. Diante da impossibilidade de conhecer o mundo das coisas, há um burburinho interminável, sons que se cruzam, preenchendo todos os espaços, confundindo os tempos. Mas ao poeta ainda resta insistir na forma, nem que seja só para enunciar a incomunicabilidade do tempo presente.

O ensaísta francês Charles Andler (1866-1933) no ensaio, de 1912, sobre a recepção ocorrida na França à publicação de $A$ alma e as formas, demonstra que uma das novidades dos ensaios de Lukács consiste na "orientação filosófica das pesquisas sobre os gêneros literários". Para Andler, Lukács, este "platônico moderno", é original pois começa a trabalhar justamente ali onde o historiador encerrou sua pesquisa; ali onde a forma é interrogada na sua relação com a vida, isto é, como abertura para a "exploração do possível" e para a "emigração da alma". Entre outras coisas, o ensaio de Lukács sobre o lírico possibilita enunciar o moderno, isto é, perceber com agudeza que a nossa sensibilidade mudou, que a poesia não pode mais ser a generalização de uma experiência interior, uma vez que não nos conhecemos mais com profundidade, não podemos mais desenhar uma "silhueta". Portanto, hoje o lirismo apenas produz "uma imagem não desenhada". Ele vasculha nossa "vida obscura"; e "sabe contemplar este mundo invisível dos sentimentos

7 Para o crítico italiano Alfonso Berardinelli, o gênero lírico torna-se, na segunda metade do século XIX, não só central, determinante, mas um gênero autônomo, pois "é uma lírica que radicaliza e especializa o gênero lírico precedente, forçando o monólogo e a audácia metafórica para as terras inóspitas de um solipsismo demoníaco, rumo à hybris de uma linguagem absoluta, tendencialmente avessa a qualquer fluência comunicativa" (BERARDINELLI, 2007, p. 143). 
obscuros". "Se não conhecemos ao fundo nenhuma alma, sabemos melhor que nossos antecessores as emoções miúdas vividas por elas em suas profundezas inacessíveis. Nós sabemos mais sobre as regiões fronteiriças nas quais vivem almas delicadas, abaladas, graciosas e, portanto, significativas. Em gestos raros, olhares dificilmente captados e palavras enigmáticas, podemos atravessar uma atmosfera tênue e penetrar sem dúvida até o mais íntimo, mas não as podemos seguir mais" (...). "Sobre sombras de azul, de malva e de esmeralda, depreendese uma imagem não desenhada para o olhar que a cria. Das modulações do acompanhamento emerge uma melodia, que parece navegar em uma onda, mergulhar e não existir mais. Assim, o lirismo contemporâneo nos mostra como uma vida superior surge espontaneamente de uma torrente vital e nos atravessa, o mais das vezes obscuramente, iluminadora de instantes decisivos de uma viva e fugidia luz interior" (ANDLER, 1988, p. 374-375).

De maneira ambiciosa, o jovem filósofo húngaro complementa a crítica estética com pistas históricas ao propor aos alemães um roteiro para uma nova História da Literatura Alemã. Assim, a evolução da poesia lírica burguesa alemã que desemboca em George teria sua origem no canto popular que começa com Günther, desenvolvendo-se com o jovem Goethe, atingindo seu melhor momento romântico com Novalis, depois com Heine e Mörike, terminando no lirismo de Theodor Storm, o último poeta lírico burguês. Portanto, antes de George a lírica antiga afirma-se com Storm em uma poesia do desaparecimento (Poesie des Vergehens). Os versos de Storm são os últimos que ainda podem ser cantados, pois a experiência vivida é afirmada neles em toda sua força, simplicidade e calma. Contudo à medida que este mundo antigo burguês começa a desmoronar e o moderno se afirmar, os versos tornam-se anacrônicos, pois continuam calmos, com uma tonalidade "morna e monótona". No artigo "O espírito burguês e a arte pela arte", de $A$ alma e as formas, Lukács elege a literatura de Storm como estrutura significativa para pensar os paradoxos de uma arte que, ao obedecer a suas próprias leis, acaba se afastando da vida, ou seja, de uma literatura que inconscientemente é adaptação e renúncia. Theodor Storm procura ingenuamente por meio de sua literatura ainda conciliar o trabalho artístico, fortemente influenciado pela "arte pela arte" dos estetas alemães (o "saber-fazer do artesão") com a maneira burguesa de viver. O resultado, contudo, é a forte presença da resignação, de uma renúncia diante do poder das coisas, visível no único prazer aceitável, que é o de realizar bem o dever e o trabalho. Como tema central, a literatura de Storm aborda apenas "aquilo que acontece aos homens, não o que fazem", isto é, a forma como os homens reagem diante dos acontecimentos que os dominam, em uma estrutura na qual sobressai uma força calma e controlada, 
pois nenhum acontecimento terá lugar nela, ou se tiver será acessório e não decisivo. O destino em Storm vem do exterior, e a força interior é impotente diante dele. Só o acaso, isto é, o encadeamento contingente de circunstâncias contingentes determina a vida de um homem. Assim, não há nada a fazer, é necessário se acomodar, renunciar a toda resistência, e experimentar o crescimento da riqueza adquirido com sacrifício, como enriquecimento da interioridade. O cotidiano acaba sendo sacralizado, afirma Lukács, pois visto como uma força mecânica que age sem o arbítrio humano.

Assim, em linhas gerais, Lukács apresenta o primeiro diagnóstico da "grandeza e tragédia da cultura alemã" — outros virão ainda mais contundentes nos escritos futuros - um racionalismo poderoso, mas que se afirma no vazio diante de uma cultura que é apenas "via interior" e "revolução do espírito". Enquanto na França os homens se tornam heróis trágicos, a Alemanha tornase uma "potência da interioridade", um país de poetas e pensadores; diante da impossibilidade de uma "revolução real", todas as energias se orientam para a vida interior.

Ao afirmar que o lirismo de George é o ponto de partida do moderno, Lukács pensa o novo não no "sentido superficial da palavra que apontaria para um lirismo intelectual", mas como lucidez e resistência contra o fatalismo da "via interior"; como "pura aspiração", "um lirismo das relações humanas", mesmo sabendo tratar-se de uma "sociabilidade interior", nos termos de George (LUKÁCS, 1974, p. 145). Ou seja, o poeta não renuncia à configuração, não se abandona ao mundo da exterioridade, como em Storm, nem aos estados de alma, como os românticos, mas busca uma forma mediadora, que vislumbre uma relação à essência, ao universal, a uma pátria; e para tal elabora uma técnica de recuo diante do empírico mediante um ritmo que "produz uma alternância entre narrativa e silêncio" (idem, p. 143). Se George é considerado, entre os simbolistas ou neorromânticos, um dos mentores da Dinggedicht, da poesia-coisa rilkeana, dos objetos tornados poéticos, com uma palavra ao mesmo tempo exata e densa, ele ostenta, para Lukács, também uma poesia crítica que coloca em suspensão tanto o mundo contemporâneo quanto o mundo histórico.

Se em Stefan George temos a busca, com poucos meios, pela forma simples, rigorosa, em uma espécie de pré-rafaelismo, diz Lukács, o outro lado, do "amor pela forma", pode ser percebido na poesia e nas novelas do vienense Richard Beer-Hofmann, outro autor pouco conhecido que Lukács elege como forma significativa, na qual temos uma escritura construída por meio da "técnica dos grandes instantes".

Por meio dos versos líricos de ambos, o filósofo afirma a forma e a sua necessidade. Em George, a forma é o que possibilita ao poeta "olhar a vida nos 
olhos", apenas para constatar que os "homens estão sós na natureza, em uma solidão mortal e sem remédio" (p. 145). Em Beer-Hofmann, a forma é o que permite um "face a face trágico", abrindo um acesso ao instante como potência soberana e simbólica (p. 196). Os instantes líricos refazem em outros termos a relação entre alma e natureza, na medida em que são "arrebatados à duração que flui indiscriminadamente, destacados da multiplicidade turvamente condicionada das coisas", permitindo à subjetividade destacar-se do tempo em nome de uma forma simbólica. O primado do instante não significa que a consciência, libertada do peso do presente e da presença dos acontecimentos externos, pode agora movimentar-se livremente em direção ao passado ou ao futuro, mas que, tragicamente, o instante é um momento de lucidez máxima no qual o sujeito confronta sua impotência diante do mundo reificado. $\mathrm{O}$ instante é concentração, ao preço de um esvaziamento do conteúdo externo. No lirismo novo temos esse instante criador de símbolos, que são "lampejos repentinos de sentido". ${ }^{8}$

Em ambos, o sentimento mais profundo da forma é "conduzir ao grande instante de emudecimento, ao "grande mutismo", e figurar a variedade da vida que se precipita, como se fosse movida apenas por estes instantes". A forma é o que possibilita a enunciação do instante de abertura para as múltiplas possibilidades e a descoberta da arbitrariedade, do acaso e das contingências. É de uma relação lúcida com a vida, e não da impossibilidade total de compreensão, que surge a percepção do abismo intransponível, e a solidão mais intensa; é no instante de compreensão mais profundo que se descobre a solidão e o poder do acaso. É o que Lukács nomeia de atração ao precipício, vertigem: o instante de lucidez, antes de cair na resignação e na renúncia às coisas.

Sabe-se que o jovem Adorno foi fortemente influenciado pelo jovem Lukács, e que diferenças significativas entre as duas trajetórias os afastaram

8 Apesar de não se referir às obras de Lukács, Eric Auerbach em vários momentos se aproxima muito da reflexão do filósofo húngaro. Por exemplo, o conceito de Moderno de Auerbach, apreendido nos romances de Virginia Woolf e de Marcel Proust, assinala também uma valorização de uma nova concepção do tempo. $\mathrm{O}$ escritor moderno abandonou-se ao acaso e às contingências, não busca mais compor e ordenar o tempo de forma completa, ao contrário, faz do instante, de um fragmento escolhido ao acaso, o elemento que libera e desencadeia "processos da consciência", realidades mais profundas, camadas de consciência que remetem a um tempo multifacetado. Mas, diferentemente de Lukács, o moderno para Auerbach não tem uma dimensão trágica, é a "confiança de que qualquer fragmento escolhido ao acaso, em qualquer instante, no curso de uma vida, está contida e pode ser representada a substância toda do destino" (Cf. AUERBACH. Mimesis, p. 480-498. 
definitivamente. ${ }^{9}$ Mas, no artigo "Lírica e sociedade", escrito por Adorno em 1950, também a propósito da lírica de George, encontramos a mesma dialética entre a linguagem e o silêncio, compreensivelmente ainda mais radical: "Para que o sujeito, aqui, contraponha-se verdadeiramente, em solidão, à coisificação, ele nem deve tentar recolher-se ao próprio como à sua propriedade (...): é preciso que o sujeito saia de si, através do calar-se. É preciso que ele faça de si como que o recipiente para a idéia de uma linguagem pura. É o salvamento desta que visam os grandes poemas de George" (ADORNO, 1980, p. 207). Em “George e Hofmannsthal: correspondência: 1891-1906", escrito entre 1939 e 1940, Adorno já anotava o radicalismo destes poetas ditos "conservadores", sem se deixar enganar pelo caráter esnobe e de falso aristocratismo, atribuído aos seus "círculos exclusivos", o que assinalava, para ele, o contexto de uma sociedade concorrencial e individualista. Mas, a despeito disso, Adorno observava que neles não havia fuga da realidade, nem abrigo em uma interioridade mística; em outros termos, o formalismo técnico resultava da percepção do "declínio da linguagem"; enfrentavam com a poesia os limites da matéria sensível, ao fazer explodir seus significados tradicionais, elaborando uma interpretação, um saber que ultrapassava, sem sucumbir aos momentos sensuais do objeto (ADORNO, p. 1998, p. 216).

Para o jovem Lukács, no princípio do século XX, contudo, o problema da arte era essencialmente o do distanciamento da vida, tornada banal, prosaica, inessencial. Em outros termos, o problema da forma era o da inscrição na vida: por isso ela se tornara problemática. A crise apontava para o desejo de pertencer a algum lugar e para a constatação de que não era possível pertencer a nenhum lugar; pois "não havia mais sentimentos comuns". Por outro lado, o racionalismo vigente apresentava-se para Lukács cada vez mais perigoso e diluidor, pois, diante de uma massa crescente de informações e conhecimentos novos, predominava uma obscura profundidade. Narramos tudo, menos o essencial; observamos múltiplas relações, mas não apreendemos uma relação real, diz ele. É porque nos aproximamos demais, com um tipo de olhar epidérmico, que não podemos entender o que vemos, desenhar sua silhueta, introduzir uma ordem. Se não há mais uma experiência comum, o desejo de completude é uma mera quimera, à qual o homem contemporâneo se agarra como o último reduto de sentido. No jovem Lukács, é recorrente o tema de que o essencial, e com ele a possibilidade de apreensão da realidade, está definitivamente perdido. Contra a "sentimentalidade" e sua promessa de uma 
pacificação idílica, a forma moderna de George ultrapassa a fácil simpatia (Mitgefühl) e não dissolve o real em "tonalidades da alma", mas caminha na realidade corporal e indiferente (LUKÁCS, 1974, p. 172).

Os temas do distanciamento e da frieza dos poemas de George remetem para outro paradoxo presente na obra de Lukács que é o da relação entre forma necessária e forma utópica. Se não há leitores, nem necessidade, por que insistem os poetas? Como situar uma forma em um período "não artístico"? Como pura teimosia, nos termos de Adorno? Ora, o vocabulário conceitual do jovem Lukács apresenta um encadeamento circular, que por vezes parece apenas perpetuar e ampliar o impasse: a necessidade da arte decorre do "princípio formador", daquilo que é autenticamente artístico, o que remete a uma "linguagem natural da manifestação", a uma "forma que é uma necessidade natural", uma "energia imediata das emoções palpitantes" e, ao fim e ao cabo, a uma "feliz coincidência entre a vida e a forma".

Em A filosofia da arte (1912-1914), Lukács sustenta que o princípio formador decorre do ímpeto criador, sobretudo de um sentimento atemporal, mas que atua no tempo: uma vontade de criar uma realidade diferente da empírica. Uma realidade absoluta, não contingente, nomeada de realidade utópica. $\mathrm{O}$ que significa que o ato criador decorre necessariamente de um distanciamento da realidade empírica, que é mobilizado conjuntamente por um impulso racional de ordenação e também por um outro irracional, quase mágico, que continua postulando uma relação à essência. $\mathrm{O}$ caminho da figuração resultaria, assim, de uma necessidade histórica, mas também de algo misterioso, platônico, fatalmente nostálgico. Como então é possível falar em épocas artísticas e em outras não artísticas? $\mathrm{O}$ artista não buscaria sempre algo em si como elemento irredutível para a realização de sua obra?

O problema da forma artística é resolvido no jovem Lukács sempre em um raciocínio circular, que oscila entre os conceitos de necessidade e utopia. Toda obra compõe um sistema fechado, dotado de racionalidade, leis, harmonia interna, etc. Um sistema que "decorre do livre jogo entre as leis e as coisas, das coisas liberadas, tornadas jogo e dança, em suas relações recíprocas" (LUKÁCS, 1981, p. 102). Ela é em sua autonomia um dado, que permanece irredutivelmente como dado. Contudo, a arte busca transformar o dado em necessidade, ou, em outros termos, ganhar alguma inteligibilidade; se a arte busca nas palavras de Novalis "um impulso em direção à pátria", tratase de uma "pátria ornamental", acrescentará Lukács, isto é, um movimento corretivo inverso: da representação da realidade para a forma pura. "É assim que o paradiso terrestre torna-se o paraíso perdido e procurado da arte: toda arte figurativa, criando uma realidade, procura esta pátria ornamental que é a 
sua, que ele abandonou por causa da realidade, e procura encontrá-la após ter atingido a realidade, nela e para ela" (LUKÁCS, 1981, p. 103).

Ora, afirmar que o artista, entendido aqui como gênio, caracteriza-se pela aspiração em direção à pátria significa para Lukács que o "signo essencial do gênio não é força e originalidade de visão, nem grandeza e profundidade de uma visão particular, mas a aliança entre estas qualidades de visão e as formas técnicas: a experiência que ganha expressão em uma forma determinada; a transformação de uma visão de mundo em visão do artista" (LUKÁCS, 1981, p. 134). Dito de outro modo, significa que a obra não desfaz os elementos dados, nem procura atacar as coisas: ela não é uma pura abstração. Mas busca uma "fraternidade entre as coisas, uma aliança entre elas, de modo que elas regressem para elas mesmas, para a sua existência simples e imanente". Há uma necessidade da obra, um a priori, apontando para uma "compleição universal" que é o impulso, a aspiração a um acabamento utópico (idem, p. 134-135). O que significa para Lukács que a obra relaciona-se com o presente em sua materialidade, ou seja, com a "hora de despertar do sono" em que as coisas regressam para elas mesmas.

Entre necessidade e utopia, o moderno afirma-se para o autor de $A$ alma e as formas não por meio dos "detalhes superficiais do quotidiano" (os "objetos" em Mallarmé?), nem pelo meramente "efêmero e transitório" baudelairianos, mas pela busca trágica pela forma, "o amor pela forma", que se desenvolve a partir de uma interioridade insatisfeita; o fato de que não se renuncia ao papel configurador demonstra que não há uma fuga romântica do presente, mas uma renúncia consciente, pois a "necessidade de se afastar da vida é o dilema trágico da modernidade" e a única atitude autêntica possível; pois "nossa maneira especificamente contemporânea de sentir, de amar e de pensar busca desenvolver seu tempo, sua configuração e sua melodia em formas, se unir em formas, se desenvolver até a forma" (LUKÁCS, 1974, p. 196). Eis o "estilo moderno": "uma questão, e em torno dela a vida; um mutismo e em torno dele, o murmúrio, o barulho, a música, o canto do todo (der Allgesang): tal é a forma" (idem, p. 188). Sempre a alternância entre o silêncio e a narrativa, jamais o domínio de um só. De modo que aqui não estamos diante do nada radical malarmeano, de um nada puro, abstrato, linguagem-pura. Mas de uma estética que tenta sem muito sucesso desembaraçar-se dos resquícios românticos.

Mas George não foi um discípulo de Mallarmé? Se em Mallarmé ou Rimbaud, por exemplo, encontramos um procedimento que cada vez mais renuncia aos meios de conexão, separando com radicalidade as coisas que se apresentam como conectadas, até que elas percam todo o contato, tornando-se 
puro estranhamento - uma espécie de desrealização da realidade sensível, ou de evasão das ordens ditas reais, como "estilhaços chegados até nós de outro mundo, por acaso" (FRIEDRICH, 1978, p. 83), em George a forma ainda nostálgica aponta o elo rompido, denuncia a realidade aniquilada, sem superála plenamente.

Assim, neste artigo sobre George, Lukács já antecipa o tema da forma moderna problemática, desenvolvido, depois, em 1916, em A teoria do romance. As canções de George são estações de uma grande viagem infinita, "que tem um alvo preciso, que não leva a nenhuma parte. Juntas, elas constituem um grande ciclo, um grande romance, completando-se mutuamente, explicando-se mutuamente, reforçando-se, serenando-se, medindo seu valor e purificandose, umas diante das outras. São os cursos vagabundos do Wilhelm Meister com talvez algo de L'Éducation sentimentale — mas construídos totalmente do interior, de uma forma totalmente lírica, sem nenhuma aventura, nenhum acontecimento" (LUKÁCS, 1974, p. 137). Se em A alma e as formas o amor pela forma, o lirismo novo, era uma resistência, em $A$ teoria do romance a tendência lírica torna-se uma fatalidade, pois Lukács radicaliza a ideia de que a "unidade foi rompida, e que não há mais totalidade espontânea do ser": o mundo esfacelado não é mais dado de forma imediata, de modo que as formas devem ser produtivas, criar a partir de suas próprias condições (LUKÁCS, 2000, p. 36). O que resulta na necessidade de uma reconsideração dos gêneros artísticos que perdem uma filosofia da história, ou seja, uma "periodicidade filosófica: aqui, os gêneros se cruzam num emaranhado inextrincável, como indício da busca autêntica ou inautêntica pelo objetivo que não é mais dado de modo claro evidente (...) o sentido histórico-filosófico da periodicidade nunca mais se concentrará nos gêneros erigidos em símbolos" (idem, p. 38).

O que acontecerá com os gêneros, então? Grosso modo, a tragédia que fala da essência afastada da vida permanece ativa até os nossos dias, embora transformada - pois o drama moderno acaba se aproximando das formas épicas; a epopéia desapareceu e dá lugar a uma forma nova, o romance; e o lírico aparece híbrido e exorbitado tanto no drama como na épica: tornando-se a lírica da alma. No caso do drama, cada dramatis personae terá de se unir somente por seu próprio fio ao destino por ela engendrado (...) e precipitarse no derradeiro e trágico isolamento (idem, p. 43-44). No caso da épica, o lírico penetra no épico alterando sua função, pois o recorte operado pelo escritor da vida empírica é de natureza lírica: "sempre é a subjetividade que arranca um pedaço da imensa infinidade dos sucessos do mundo, emprestalhe uma vida autônoma e permite que o todo do qual ele foi retirado fulgure no universo da obra apenas como sensação e pensamento dos personagens, 
apenas como o desfiar involuntário de séries causais interrompidas, apenas como espelhamento de uma realidade que existe por si mesma" (LUKÁCS, 2000, p. 48). "O ato pelo qual o sujeito confere forma, configuração e limite, essa soberania na criação dominante do objeto, é a lírica das formas épicas sem totalidade. Essa lírica é aqui a unidade épica última” (idem, p. 49). Há, contudo, nuances nos casos do idílio e da novela, nos quais a "realidade do real, o elemento exterior não é dissolvido" (idem, p. 50).

Em todo caso, o lírico é, antes de tudo, exacerbado, ou seja, torna-se um "poder": "quando uma alma é o herói e a sua aspiração o enredo". Mas um poder esvaziado, dessacralizado, "pois o círculo que ele traça ao redor daquilo que seleciona e circunscreve como mundo indica somente o limite do sujeito, e não o de um cosmos de algum modo completo em si mesmo" (idem, p. 52). Ele pode produzir unidades de composição, mas não a verdadeira totalidade. Na tipologia realizada em $A$ teoria do romance, na tendência nomeada de romance de desilusão, Lukács localiza a maior penetração do lírico, a maior inadequação entre a alma e a realidade, pois a "alma é mais ampla e mais vasta que os destinos que a vida é capaz de lhe oferecer". O mesmo é sustentado, posteriormente: "pois também a subjetividade lírica conquista para os seus símbolos o mundo externo, ainda que este seja auto-criado, ele é o único possível, e ela, como interioridade, jamais se opõe de maneira polêmicarepreensiva ao mundo exterior que lhe é designado, jamais se refugia em si mesmo para esquecê-lo, mas antes, conquistando arbitrariamente, colhe os fragmentos deste caos atomizado e os funde - fazendo esquecer todas as origens - no recém-surgido cosmos lírico da pura interioridade" (LUKÁCS, 2000, p. 120).

A exacerbação e fatalidade do lirismo apontam para a solidão e não para alguma forma de redenção. A solidão como a verdadeira essência do trágico, "pois a alma que se fez a si mesma destino pode ter irmãos nas estrelas, mas jamais parceiros" (LUKÁCS, 2000, p. 43). Uma solidão teatralizada, dirá Adorno anos mais tarde, a propósito de George e, especialmente, de Hofmannsthal, pois gesto consciente do poeta moderno que sabe os limites da narração na sociedade administrada, e que a busca pela linguagem pura é realizada em chave irônica, como "teimosia" diante da "linguagem reificada e banal das mercadorias"; o poeta do moderno deixa-se submeter pelo poder das coisas: "em vez de as coisas se apresentarem como símbolos da subjetividade, esta se apresenta como símbolo das coisas, pronto a petrificar-se em coisa, na qual de todo modo já foi transformada pela sociedade" (ADORNO, 1998, p. 219). Contudo, o poeta ganha também o pressentimento do seu contrário. Eis o prêmio por sua "afetação estética: ele representa a utopia de não ser 
ele mesmo", ou seja, significa aquilo que a dialética do jovem Lukács intuía tristemente: o esteta rompe com seu "barulho silencioso", o "contrato social da felicidade" (idem, p. 220-221).

No que diz respeito ao lírico, a relação entre Lukács e Adorno foi especiosamente bem apontada por F. Jameson: A teoria do romance é uma chave teórica para Adorno, pois aponta para o esfacelamento da realidade, percebida agora apenas por meio de fragmentos de consciência, isto é, do ponto de vista dos gêneros, o elemento lírico penetrou no romance, alterando a função e o sentido do épico: doravante, isto é, na modernidade, o narrador só pode enunciar um conteúdo que foi transformado pela subjetividade (JAMESON, 1997, p. 268-269). Só há o monólogo, mesmo que o discurso comunicativo procure ocultar. As diferenças entre Lukács e Adorno são, contudo, marcantes e apontam para uma exacerbação do referencial histórico em Adorno. Para o primeiro, a obra de arte foi e permanecerá sendo um momento de configuração de um sentido utópico, para o último, elas só podem ser "signos de interrogação". Para Adorno, a obra enquanto enigma exige distância e permanência do caráter enigmático, não há uma experiência imanente que dê conta de sua significação: "O conteúdo de verdade das obras de arte é a resolução objetiva do enigma de cada uma delas, afirma Adorno. Ao reclamar uma solução, o enigma remete ao conteúdo de verdade. Este só se pode obter mediante a reflexão filosófica. Eis o que justifica a estética" (ADORNO, 2004, p. 174).

\section{Referências}

ADORNO, T. W. George e Hofmannsthal: correspondência: 1891-1906. In: Prismas, crítica cultural e sociedade. São Paulo: Ática, 1998.

ADORNO, T. W. Palestra sobre lírica e sociedade. São Paulo: Abril Cultural, 1980. (Os Pensadores).

ADORNO, T. W. Teoria estética. Madrid: Akal, 2004.

ANDLER, Charles. La vie de l'âme et la gênese des formes littéraires. In: Le Parthenon, n. 2, 19, 1912. In: Az ifjú Lukács a kritika tukrében. Budapest: Lukács Archívum, 1988.

ÁRPÁD, Tímor. Lúkacs györgy ifjúri müveinek fogadtatása magyarországon. In: $A z$ ifjú Lukács a kritika tükrében. Budapest: Lukács Archívum, 1988.

BERARDINELLI, Alfonso. Da poesia à prosa. São Paulo: Cosac Naify, 2007.

FRIEDRICH, Hugo. Estrutura da lírica moderna. São Paulo: Duas Cidades, 1978.

GEORGE, Stefan. Crepúsculo. Tradução de Eduardo de Campos Valadares. São Paulo: Iluminuras, 2000. 
HEGEL, G. W. F. Cursos de estética. Tradução de Marco Aurélio Werle. São Paulo: Edusp, 1999. v. 1.

HEGEL, G. W. F. Cursos de estética. Tradução de Marco Aurélio Werle e Oliver Tolle. São Paulo: Edusp, 2004. v. 4.

JAMESON, Fredric. O marxismo tardio. São Paulo: Unesp: Boitempo, 1997.

KANT, Immanuel. Crítica da Faculdade do Juizo. Rio de Janeiro: Forense Universitária, 1993.

LUKÁCS, Georg. A teoria do romance. Tradução de José Marcos de Macedo. São Paulo: Ed. 34, 2000.

LUKÁCS, Georg. Die Seele und die Formen: Essays. Berlin: Luchterhand, 1971.

LUKÁCS, Georg. Heidelberger Ästhetik (1916-1918). Darmstadt: Luchterhand, 1975.

LUKÁCS, Georg. Heidelberger Philosophie der Kunst (1912-1914). Darmstadt: Luchterhand, 1974.

LUKÁCS, Georg. L'ame et les formes. Paris: Gallimard, 1974.

LUKÁCS, Georg. Pensée vécue, mémoires parlés. Paris: L'Arche, 1986.

LUKÁCS, Georg. Philosophie de l'art (1912-1914). Paris: Klinksieck, 1981.

LUKÁCS, Georg. Probleme des Realismus III. Berlin: Luchterhand, 1965.

SCHLEGEL, Friedrich. Sobre el estúdio de la poesia grega. Madrid: AKAL, 1996.

SCHOPENHAUER, Arthur. Metafísica do Belo. São Paulo: Ed. UNESP, 2003.

WERLE, Marco Aurélio. A poesia na estética de Hegel. São Paulo: Humanitas: Fapesp, 2005. 